\title{
The Philosophy of management ideas
}

\begin{abstract}
The philosophies which underpin studies of management ideas are rarely interrogated, which, it is argued here, leads to several difficulties for research in this field. This chapter makes explicit four philosophies which commonly underpin work in this field, and argues that, among other limitations, their ontological strictures make interdisciplinary communication difficult. The chapter introduces a critical realism, arguing that its stratified, emergent and realist ontology can (partially) integrate the strengths from these philosophies, whilst ameliorating their respective weaknesses. Finally, the chapter sketches out a critical realist conception of management ideas.
\end{abstract}

\section{Keywords:}

Management ideas; Ontology; Social constructivism; Critical Realism; Positivism; Interactionism

\section{Introduction}

Whilst the management literature is replete with claims about the sources, creation, evolution, diffusion, translation and destruction of ideas, it is rare that academics ask explicitly what 'management ideas' actually are. This absence is surprising because these terms often specify things that can happen to ideas in the context of management and organization or the broader society, and implies both that ideas have properties which regulate what they can and cannot do, and that we can have some knowledge of these properties. This implies, therefore, something about the ontology (what is) and epistemology (what can be known) of management ideas, and places these claims firmly within the realm of philosophy. Whilst there are a few studies that do seek to define ideas (Sturdy 2004, Birkinshaw et al. 2008), they tend to focus on the different themes or perspectives (McKinley et al. 1999) on management ideas, rather than the various ontological or epistemological assumptions that authors make about what management ideas actually are, let alone which of these might be more useful (or indeed correct) than others.

The absence of philosophical interrogation concerning management ideas has led to three problems. First, clarity. Texts tend to assume that the concept under consideration is a management idea, with little justification, or specification of why this might be the case. Wider questions concerning, for example, if ideas actually exist, if so in what sense, and what this means for what they can do, are all but ignored. One consequence is that although the use of verbs such as 'diffuse', 'translate' or 'evolve' imply something very specific about what can happen to an idea, it is often left to readers to infer exactly what these are. As an illustration, one might type "management idea" and "evolution" into Google Scholar and see how many of the articles really mean, let alone define, specify a Darwinian or Lamarckian form of evolution. Second, interdisciplinary. The confusion as to the status of management ideas is exacerbated by the variety of perspectives and associated terms which are deployed. If I am talking about ideas, and you are talking about innovations, fashions, concepts, services, practices, or routines, how do we know the extent to which our work might be complementary unless we know what it is we are talking about? As we shall see, the claimed and implied philosophical underpinnings 
of different conceptualisations of management ideas has led to disciplinary siloes which tend to ignore each-other whilst tackling similar topics. Finally, veracity. It is one thing to clarify what we think ideas are, but another to accept that these definitions are adequate. Management ideas are generally attempts (though often flawed) to conceptualise how organisations respond to interventions. In other words, explicitly or otherwise, they make truth claims: not only in theorising causality, but also in critiquing prior truth claims as misguided, limited or wrong. It follows that, at least in the minds of most academics, there are more or less accurate ideas, not only of what 'works' in organisations, but also of why. In short, some academic conceptualisations of management ideas are more accurate reflections of reality than others and without knowing what these are, we are in little position to compare their relative veracity.

In responding to these weaknesses, this chapter clarifies and critiques what management ideas are assumed to be in the extant literature, and discusses the possibilities of an alternative more integrative approach. The paper first discusses the possibilities and limitations of four different but influential philosophies (which are often implied rather than declared) concerning what management ideas are: positivism, actualism, interactionism, social constructivism. In identifying these, several caveats must be made. First, whist the four philosophies represent the vast majority of perspectives in the extant literature (see for example, O'Mahoney 2016) they are by no means exhaustive. The negative ontology of Laclau and Mouffe (2001) or the sociomaterial theorising of Barad (2007), for example, are not detailed here as they are rarely, if at all, used in the literature. Second, the four perspectives have been termed philosophies because they represent relatively coherent associations of ontology and epistemology with corresponding consequences for methodology. However, as we shall see, they are rarely strictly adhered to by academics exploring management ideas. Most commonly, philosophies are implied within texts, or, even when they are claimed, are not adhered to throughout (O'Mahoney 2016, O'Mahoney 2011). Moreover, there is not a one-to-one matching between these philosophical perspectives and the themes/approaches identified by others - for example, institutional theory implies and states a variety of philosophical approaches to understanding the institutionalisation of ideas.

Following the discussion of the possibilities and limitations of these four perspectives, the paper then develops, and argues for, the utility of an explicitly critical realist conceptualisation of (management) ideas as a more integrative, realistic and useful approach to studying management ideas, and the world in which they exist.

\section{Management ideas}

This section identifies four philosophical approaches to management ideas and outlines their strengths and weaknesses, first individually, and then collectively.

\section{Positivism}

One of the popular approaches to studying management ideas focuses on citation analyses (primarily papers in journals and newspapers) and surveys (e.g. Ehigie and McAndrew 2005). Here, the focus tends to be on population level movements of ideas and thus is particularly well suited to identifying patterns of the longitudinal dynamics of ideas and proposing potential influences on these, such as types of entrepreneurs, socio-economic context, and quality of consultancy (e.g. Strang et al. 2014, Abrahamson and Fairchild 1999). 
Studies using this approach often make several (generally implicit) assumptions about the nature of the concepts they study which indicate an underlying philosophy which contains several principles. First, positivist studies (sometimes termed 'scientism' or 'naïve realism') often assume that reporting of the concept through citations or surveys can tell us something about the actual concept in practice. Whilst this assumption is occasionally mentioned in papers' 'limitations' sections, it is never held to be so significant as to undermine the conclusions of the study. Of course, it may be true that such methods can tell researchers something about the existence of ideas, but it may also not be true (Benders et al. 2007). What is often missing from studies is a discussion of the conditions in which the former or the latter may be the case, and the extent to which such conditions are evident in the study in hand. At worst, this is an example of what Bhaskar calls the epistemic fallacy: 'the view that statements about being can be reduced to statements about knowledge' (Bhaskar 1975: 36). The conflation of epistemology and ontology is problematic for several reasons, not least because, where detailed work has been done, the reporting of management fashions is often shown to be at odds with their observed existence (for example, Collinson et al. 1998).

Second, in generalising about, say, TQM, from surveys or citations of TQM, these approaches often imply a Platonic view of existence: that there is a 'real' innovation which is distinct from the empirical manifestations which are measured. Such studies often assume that the reported innovations are the same, or at least have a core set of features, which make them TQM. This type of thinking is Platonic at heart because it assumes we can know something about an idealised form of innovation from its empirical manifestations. Additionally, studies sometimes do not confine themselves to descriptive efforts (i.e. the instances in their survey or citation group) but go further to make predictive prescriptions i.e. that a successful implementation will follow if conditions $A, B$ and $C$ are met (for example, Terziovski et al. 2003). A collorary of assuming a Platonic ideal form, is that the 'real' innovation is unchanging and eternal: generally the conceptual form of what is being studied is assumed to be temporally static (if it were not, the prescriptions and correlations would not be possible). This absence is often exacerbated by the tendency of this perspective to focus on the diffusion phase of a lifecycle rather than the creation / destruction periods (Clark 2004). As a consequence, it is often, though not always, assumed that the empirical implementation is binary in existence i.e. that it is either implemented completely or not. This is an atomistic assumption, which as we see below, makes statistical analyses easier but is out of kilter with the ongoing, emergent and processual nature of business transformation. Ontologically, these approaches certainly involve a form of realism, but it is a form of what Sayer calls 'naive realism' such that 'the appeal to facts ... involves collapsing statements into their referents, thought objects into real objects. It thereby appears to appeal to the facts themselves, the way the world is, in an unmediated fashion' (Sayer 2010, p. 42).

In focusing on the diffusion of innovations through statistics, positivist methods parallel natural science approaches such as pathology, epidemiology or demography (Rahmandad and Sterman 2008). The approach of diffusion studies therefore often implies that change is 'subject to the laws of physics' (Czarniawska 2012: 12), such that, when variables A, B and C are in alignment, an innovation or idea will spread or be implemented 'successfully' (e.g. Ceci and lubatti 2012). The positivist assumptions of such approaches are most evident in the regression analyses that are often performed to highlight the dependencies and mediators of diffusion. The necessary assumption of regression analyses in this sphere is that the social world is a 'closed system' i.e. that whenever $X$ occurs, then $Y$ will follow ${ }^{1}$ (Fleetwood and Hesketh 2015). In diffusion studies, X might be distributed leadership, strong

\footnotetext{
${ }^{1}$ As Fleetwood and Hesketh (2015) show - the fact that this relationship may be mediated, probabilistic or have multiple relationships, in no way detracts from the closed-system assumption.
} 
communications, or performance management, and $Y$ is generally some measure of the 'success' of any idea (whether by diffusion or effectiveness).

For regression analyses to work, a closed system (such as a laboratory) or a relatively closed system (such as the body) must provide stable mechanisms which allow inputs to be regularly followed by outputs. The question of whether this can ever be the case for the social sciences is one beyond the scope of this chapter (see Fleetwood and Hesketh 2015), but it a precondition of regression analyses used for predictive purposes that it occurs in a closed systems of atomistic events. For example, Waarts and Van Everdingen (2005) use regressions to argue that national cultures 'highly significantly' explain variance in the diffusion and adoption of ERP systems, with the generalization that 'we can safely conclude that national culture does influence the individual adoption decisions of companies' (p. 608). Here, diffusion is 'explained' by its correlation to measures of culture. Regardless of the accuracy of both these measures, the correlation or relation between ERP and completed questionnaires about culture are taken to be causal with minimal understanding of how the two may be related. The statistical emphasis of such papers mean that hard-to-measure and complex mediators do not get included (for example, human agency).

\section{Interactionism}

In contrast to the atomism and empiricism implied by diffusion studies, interactionism focuses on the role of inter-group communication, co-operation and boundaries in creating, translating and implementing management ideas (Wenger 1999, Bechky 2003). Rather than focusing on the entity of the idea, the interactionist perspective emphasises the dynamic role of local knowledge construction and sense-making which reconstruct ideas as they transgress organisational or group boundaries. As ideas 'mean different things in different worlds [and] actors are faced with the task of reconciling these meanings if they wish to cooperate' (Star and Griesemer, 1989: 388) the methodological focus of this perspective tends towards interpretivist methods such as ethnography or participant observation, which are suited to understanding the meanings which different communities generate. Empirically, interactionist studies tend to focus on different professional, hierarchical, or occupational 'communities of practice' that have disparate understandings of ideas (Swan et al. 2007). The construction of meanings frequently involve 'boundary objects' (such as strategy tools or engineering diagrams) which provided a basis for communication as they 'inhabit several intersecting social worlds and satisfy the informational requirements of each of them' (Star and Griesemer 1989: 393).

As a philosophy, interactionism focuses on the construction of meanings though human relationships and related emergent phenomena such as consciousness and language (Blumer 1986). It has its theoretical roots in the American pragmatist tradition (Peirce 1998) which emphasises the usefulness of truth statements to the groups using them and its roots can be traced to the symbolic interactionism of Strauss (1959) and Blumer (1962). Such approaches prioritise rather than decentre the human from their analyses. Yet, whilst writers in this tradition focus on the construction of meanings, interactionism is 'quite definitely rooted in ontological realism' (Porpora 2015: 67). As Blumer wrote 'I shall begin with the redundant assertion that an empirical science presupposes the existence of an empirical world. Such an empirical world exists as something available for observation, study and analysis' (Blumer 1969 p21). Yet, this realism is more often implied when interactionism is used to study management ideas, with authors accepting (or at least implying) that real things such as roles, production systems, or technology impinge upon social interactions, sense-making and meaning construction (see, for example, Annels 2010: 21). Boundary objects, for example, are taken to be 'both concrete objects and abstract concepts' (Swan et al. 2007) and are argued to be 'embedded in social 
structures' (Pawlowski and Robey 2004). However, the focus of this perspective is less on external realities but on the local construction of shared meanings by different groups, thus, epistemologically, writers tended towards relativism and use methods sensitive to the construction of meaning, such as ethnomethodology, anthropology or case-study research.

The focus of interactionism on meaning making is both enabling and limiting. Ethnomethodological approaches enable insights into the processes by which meanings are translated between groups to enable their co-operation, but the emphasis on the distinct communities of practice within organisations, as opposed to their wider social and cultural context, can mean that important commonalities are over-looked. For example, Swan et al. (2007: 1833) analyse boundary objects which help different communities of practice (i.e. researchers; clinicians; scientists) 'reveal and accommodate differences in perspective and, therefore, reconcile differences in meaning to create a common understanding'. Yet, in common with many other studies from this perspective, their analysis neglects the wider social and structural context of these 'communities'. It fails, for example, to include their many commonalities: they are all English-speaking, degree educated and professional. Moreover, they are all employed by the same company, and as such are constrained by common social structures, for example, organisational rules, cross-departmental routines and employment contracts. Such commonalities not mean that there are many other opportunities for creating shared meanings but also that wider social structures might play an important part in enabling the communicative practices that the paper seeks to highlight.

\section{Actualism: Actor Network Theory (ANT)}

An increasingly popular approach to understanding management ideas, and especially their movement is actualism, the most common form of which is Latourian ANT studies. For Latour, and those that do not misinterpret his work (e.g. Luoma-aho and Paloviita 2010), management ideas are not lasting entities but temporary events ('actors'), which are enabled by a specific and temporary alignment of other events within a network of relations. Yet, the network is neither determined not inevitable, as actors are enrolled and institutionalised into networks by other actors through the translation of their interests or representations. Such enrolment (called interessment by Latour) often involves the use of rhetoric, persuasion, and argument to shift the interests of actors in order to build alliances that enable the implementation or spread of management ideas (e.g. Robinson et al. 2010, Giroux 2006). Often such efforts involved the creation of an 'obligatory point of passage' whereby the representation of actors is colonised by one group. Other ANT papers focus on the translation of an entity through an actor-network. For example, Sandhu et al. (2008) detail the differentiated translation of a balanced scorecard implementation through a network of human and non-human actors. This approach is consistent with ANT, but focuses not on the establishment of an actornetwork, but the subsequent spread of ideas (called 'tokens') across that network (Latour 2007).

The ontology of ANT is 'proudly' actualist and anti-essentialist (Harman 2009: 16), rejecting social structures or invisible motivations in favour of tracing the empirical networks between actors (Latour and Woolgar 1986, Latour 2007). Yet, as with the positivist approaches, ANT has a 'flat' realist ontology, rejecting any emergent or structural forms of existence in favour of a focus on events. Whilst, ontologically realist, ANT is epistemologically constructivist (see also, Elder-Vass 2008), in that whilst real objects exist 'out there' they come into being through the practices of science - which is itself seen as another actor-network (Latour and Woolgar 1986). Indeed, as it is the network which lends properties and powers, humans and non-humans are treated symmetrically: things are only what they 'come to be in a relational, multiple, fluid, and more or less unordered and indeterminate 
(set of) specific and provisional practices' (Law and Mol 2008: 365). For this reason, ANT often decentres the human from its accounts, and emphasises the agency of non-human 'material actors'.

Yet, the ontological strictures of ANT cause difficulties. Harrisson and Laberge (2002), for example, use ANT to examine a change project at a multinational company. Based on a view of ANT that, 'to obtain the consent of actors and form an alliance with them, their desires and needs must be interpreted', the analysis sought to understand how the management idea was 'presented, discussed and debated' and how the interests of actors were translated using 'appeals, persuasion and use of convincing language' (p.148). To achieve this, the authors highlight how interessement was attempted by emphasising messages of job security and higher wages. However, the highly actualist ontology of ANT, which rejects the concept of social structure, results in an analysis which excludes the wider social forces that might play a significant role in understanding the workers' capacity for resistance such as national culture, employment levels, firm ownership, national laws, and class. For example, the ability of, say, migrant workers to resist a change in China (Smith and Pun 2006) is probably significantly less than the skilled engineers Harrisson et al. studied in Canada - yet as the analysis focused solely on how the idea was presented and debated, we are given little idea of if, and why, this might be the case.

In highlighting the importance of empirical networks in enabling and constructing change, ANT's methodology provides powerful insights into how management ideas spread; However, by rejecting social structures, and the power which this implies, the question of why ideas spread is often left unanswered ${ }^{2}$ (Elder-Vass 2008). For example, both Guilloux et al. (2013) and Strong and Letch (2013) use ANT to describe how the translations of interests that enabled IT-led change in their cases. Yet, both struggle to explain why key actors such as regulators played such a powerful role without recourse to structural explanations. Others, such as Harrison et al. (2002) struggle to restrict their analysis only to actual events, often using emergent concepts such as roles, routines or social structures which Latour explicitly rejects. This limitation is especially evident when seeking to understand the impact of organisations on management ideas, the former of which are highly structured phenomena (Mutch 2007).

\section{Social constructivism}

Another common approach to understanding management ideas is social constructivism - an approach often associated with 'Scandinavian Institutionalism' (Czarniawska and Sevón 1996). This perspective tends to focus on the construction and re-construction of management ideas through the discourses and 'micro-politics' (Reay et al. 2013). Indeed, the 1990s and 2000s provided fertile publishing ground for scholars that wished to show the utility of Foucault in understanding the selfdisciplining effects of discourses of managerialism, TQM, BPR, 'Quality', strategy, New Public Management, Lean and many others, on workers (e.g. Knights et al. 2003).

Management ideas for social constructivists tend to be framed within a relativist epistemology which rejects the 'grand narratives' or generalisable laws associated with scientism. This approach suggests

\footnotetext{
${ }^{2}$ This is a tension that Latour embraces and 'very deliberately seeks to elide "how" and "why" questions' Bijker, W. E. \& Law, J. 1992. Shaping Technology/building Society: Studies in Sociotechnical Change. USA: MIT Press.. Yet, clearly the answer to (for example) 'how was TQM implemented?' provides little insight into the question 'why was TQM implemented?'.

${ }^{3}$ Although many Scandinavian Institutionalists claim a Latourian heritage, these are rarely put into practice, and indeed Latour often appears to be misunderstood by these writers as a social constructivist. See O'Mahoney (2016) for more detail on this.
} 
that knowledge of an extra-discursive 'external' world is not possible, 'either because it is claimed there is no external reality outside of texts or discourses (strong social constructivism) or because if there is an objective reality, we can know nothing about it (weak social constructivism)' (O'Mahoney and Vincent 2014: 724). Here, discourses or narratives are emphasised through the inclusion of many social constructivist theorists in these papers, especially Foucault (e.g. Kelemen 2000). These texts also tend to commit to an anti-essentialist position which applies not only to ideas, but also to all other entities such that organisations, subjects, and indeed the social world are only social constructions.

This presentation of management ideas as created, disseminated and known through discourses encourages scholars to use intensive methods suited to identifying and understanding discourses, such as interviewing and discourse analysis, to enable insights into how ideas are constructed, known and translated. Empirically, this results in a variety of approaches: for example, some writers focus on the construction of management ideas by management consultants, publishers, gurus and business schools (e.g. Sahlin-Andersson and Engwall 2002) whilst others have explored the processes that agents enact when translating ideas into local contexts - for example the rules that inform 'editing' activities when putting ideas into practice (e.g. Morris and Lancaster 2006). Moreover, the understanding of management ideas as constructed through local discourses, as well as having constructive effects, calls attention to ideas as dependent on the politics and rhetorics of legitimation that actors deploy in organisations (e.g. Czarniawska-Joerges and Sevón 2005).

However, this focus, especially if kept within the bounds of social constructivism, can be limiting when the focus on the local and discursive misses the non-local, structural and population-level embeddedness of an innovation, which can help explain its success or failure (Fleetwood 2005). Frandsen (2010), for example, when examining the implementation of management accounting in a hospital, shows how discourses of accounting 'discipline' nurses' work and 'create truths about them as individuals and their abilities' (p.338). Whilst enlightening, this argument misses not only some of the important structural aspects of the case that we discussed regarding ANT (such as unionisation, type of organisation, social context and national laws), but its anti-essentialist ontology means that the characteristics of any particular innovation - its price, whether it works, whether it is easy to implement - are sacrificed to the discursive representation of the innovation: such as whether management say it works. Moreover, this anti-essentialism also applies to the nurses themselves whose 'truths' are ostensibly created by the accounting discourse. As many have argued (e.g. Thompson and Ackroyd 1995) this form of social constructivism makes resistance to management ideas difficult to conceptualise as it empties the individual of non-discursive properties. 


\begin{tabular}{|c|c|c|c|c|c|c|}
\hline $\begin{array}{l}\text { Philosophical } \\
\text { approach }\end{array}$ & Ideas as... & $\begin{array}{l}\text { Ontological } \\
\text { commitments }\end{array}$ & $\begin{array}{l}\text { Epistemological } \\
\text { assumptions }\end{array}$ & $\begin{array}{l}\text { Methodological } \\
\text { preferences }\end{array}$ & Possibilities & Limitations \\
\hline $\begin{array}{l}\text { Positivism (naive } \\
\text { realism; } \\
\text { scientism; } \\
\text { empiricism) }\end{array}$ & $\begin{array}{l}\text { The population level } \\
\text { spread of empirical } \\
\text { manifestations of } \\
\text { implementations over } \\
\text { time / space. }\end{array}$ & $\begin{array}{lr}\text { Essentialism; } & \text { Atomism; } \\
\text { Naïve } & \text { realism; } \\
\text { Empiricism; } & \end{array}$ & Objectivism & $\begin{array}{ll}\text { Quantitative } & \text { extensive } \\
\text { methods (e.g. } & \text { surveys / } \\
\text { citations); } & \text { Regression } \\
\text { analyses; } & \end{array}$ & $\begin{array}{l}\text { Macro-level view; } \\
\text { rationality of the } \\
\text { agent; }\end{array}$ & $\begin{array}{l}\text { Confuses survey / citation data with empirical } \\
\text { reality; Produces 'thin' explanations; agency } \\
\text { often excluded or presented as purely } \\
\text { rational. }\end{array}$ \\
\hline $\begin{array}{l}\text { Actualism (e.g. } \\
\text { Actor Network } \\
\text { Theory) }\end{array}$ & Empirical events. & $\begin{array}{l}\text { Ideas as events; Change } \\
\text { through empirical } \\
\text { networks; Realist. }\end{array}$ & Constructivist & $\begin{array}{l}\text { Intensive methods; 'Follow } \\
\text { the network'; } \\
\text { Ethnomethodology; }\end{array}$ & $\begin{array}{l}\text { Empirical networks; } \\
\text { De-centres the } \\
\text { human; Agency of the } \\
\text { non-human; }\end{array}$ & $\begin{array}{l}\text { Excludes non-empirics (e.g. motivations; } \\
\text { interests; structures). ANT treats humans as } \\
\text { equivalent to non-humans; Difficulty with } \\
\text { 'why' questions; }\end{array}$ \\
\hline $\begin{array}{l}\text { Social } \\
\text { constructivism }\end{array}$ & $\begin{array}{l}\text { Discursive } \\
\text { constructions. }\end{array}$ & $\begin{array}{l}\text { Discourse; anti- } \\
\text { essentialism; }\end{array}$ & Relativism & $\begin{array}{lr}\text { Intensive } & \text { methods; } \\
\text { Discourse } & \text { analysis; } \\
\text { Deconstruction; } & \\
\text { Interviewing; } & \end{array}$ & $\begin{array}{l}\text { The socially } \\
\text { constructed nature of } \\
\text { innovations; micro- } \\
\text { level politics. }\end{array}$ & $\begin{array}{l}\text { Focus on the local can miss the wider macro- } \\
\text { level view; Focus on discourse means structure } \\
\text { and the material get ignored; Difficulties } \\
\text { conceptualising resistance. }\end{array}$ \\
\hline $\begin{array}{l}\text { Symbolic } \\
\text { Interactionism }\end{array}$ & $\begin{array}{l}\text { Cultural constructions of } \\
\text { meaning by local } \\
\text { groups. }\end{array}$ & $\begin{array}{l}\text { Communicative } \\
\text { relationality; Local } \\
\text { cultural construction of } \\
\text { meanings. }\end{array}$ & $\begin{array}{l}\text { Relativism; } \\
\text { Pragmatism; }\end{array}$ & $\begin{array}{l}\text { Interpretivist } \\
\text { methods } \\
\text { anthropology; } \\
\text { ethnography) }\end{array}$ & $\begin{array}{l}\text { Boundaries; Inter- } \\
\text { group communication } \\
\text {; The power of objects } \\
\text { in enabling co- } \\
\text { operation; }\end{array}$ & $\begin{array}{l}\text { Ignores commonalities from wider social \& } \\
\text { cultural context; Tends to under-play social } \\
\text { structures (e.g. rules; routines; roles) }\end{array}$ \\
\hline
\end{tabular}


The limitations of the philosophies detailed above originate, I argue, from their ontological and epistemological principles. These not only limit their methodological power, but also their ability to engage with each-other. A major reason for this, I suggest, is the different conceptions of what an idea is. Positivism tends to frame management ideas as reports of implementations (in citations or surveys); actualism sees ideas as events; constructivism represents ideas as discursive constructions; and interactionism, whilst less uniform in its approach, tends to see ideas as meanings produced by local communities. Other than the siloed nature of academic studies in this field, which can limit their analytical insights (Joseph and Roberts 2003), these rather narrow definitions prompt the question, can management ideas not include all these aspects, and others? The remainder of this paper points to an alternative, more ecumenical, philosophy, that helps integrate some of the strengths of the four philosophies detailed above whilst ameliorating some of the weaknesses.

\section{Critical realism ${ }^{4}$ : an ecumenical philosophy?}

Critical realism (CR) is an ontology developed by Roy Bhaskar $(1975,2011)$ which holds that reality exists at different emergent 'levels' which are dependent upon, but irreducible to each-other (for example, atoms, cells, organisms, minds, people, teams, organisations, society). It argues that reality is stratified, and distinguishes between the real (underlying causal mechanisms), the actual (empirical epiphenomena) and the empirical (perceptions of the actual). It is, therefore, epistemologically relativist, but, crucially, with a commitment towards judgemental rationality (the human ability to judge between better and worse theories about the world). CR holds that things ('entities') such as organisations, ideas or money, have properties and powers (e.g. to employ, to change behaviours, to purchase) which affect other entities, and exist independently of our talk about them. With reference to methodology and 'domain level theory' (i.e. theorising at a field or subject matter level), CR is quite ecumenical: 'there are no specifically CR methods of research....there is a valid and important place for all the methods sociologists have employed - although not necessarily in the way they have employed them' (Porpora 2015: 63).

CR theorising is useful for theorising management ideas because it helps integrate the strengths of the perspectives above whilst combating some of their weaknesses. If we take the strengths first, we can see from Table 2, that each strength (taken from Table 1) relates to a different theoretical aspect of critical realism with which it can engage.

\footnotetext{
${ }^{4}$ Critical realism has developed variants over the years including Bhaskar's 'spiritual turn' and his later work on dialectical critical realism. Whilst I believe the latter, specifically, offers interesting opportunities for understanding management ideas, there is no space here to expand upon it. For the purposes of this chapter, I focus on the original critical realist principles laid out by Bhaskar in his first three books.
} 
Table 2 The possibilities of CR for engaging the strengths of philosophies of management ideas

\begin{tabular}{|c|c|c|c|}
\hline Philosophy & Strengths & Category & Critical realist engagement \\
\hline \multirow[t]{2}{*}{$\begin{array}{l}\text { Positivism } \\
\text { (Scientism) }\end{array}$} & $\begin{array}{l}\text { Macro-level } \\
\text { view }\end{array}$ & Emergent levels & $\begin{array}{l}\text { Emergence accepts the population view of } \\
\text { ideas / innovations, and, suggests these are } \\
\text { dependent on but irreducible to 'lower' levels. }\end{array}$ \\
\hline & $\begin{array}{l}\text { Rationality of } \\
\text { the agent }\end{array}$ & $\begin{array}{l}\text { People \& } \\
\text { relations }\end{array}$ & $\begin{array}{l}\text { People are entities that possess a number of } \\
\text { properties and powers, one of which is (limited } \\
\text { and bounded) rationality. }\end{array}$ \\
\hline \multirow[t]{3}{*}{$\begin{array}{l}\text { Actor-Network } \\
\text { Theory (Actualism) }\end{array}$} & $\begin{array}{l}\text { Empirical } \\
\text { networks }\end{array}$ & $\begin{array}{l}\text { Stratified } \\
\text { ontology }\end{array}$ & $\begin{array}{l}\text { The empirical networks (i.e. connected events) } \\
\text { in ANT are, for CR, the domain of the 'actual'. }\end{array}$ \\
\hline & $\begin{array}{l}\text { De-centres } \\
\text { the human }\end{array}$ & $\begin{array}{l}\text { People \& } \\
\text { relations }\end{array}$ & $\begin{array}{l}\text { CR promotes a complex view of the human as } \\
\text { emergent (cells, organs, minds, action, } \\
\text { rationality etc.). However, it does not accord a } \\
\text { 'special' to humans over and above the powers } \\
\text { and properties we hold. For example, it accepts } \\
\text { the agency of the non-human. }\end{array}$ \\
\hline & $\begin{array}{l}\text { Agency of the } \\
\text { material }\end{array}$ & $\begin{array}{l}\text { Entities, Powers } \\
\text { \& Mechanisms }\end{array}$ & $\begin{array}{l}\text { CR accepts that material entities have powers } \\
\text { and properties. }\end{array}$ \\
\hline \multirow[t]{2}{*}{$\begin{array}{l}\text { Social } \\
\text { constructivism }\end{array}$} & $\begin{array}{l}\text { The socially } \\
\text { constructed } \\
\text { nature of } \\
\text { ideas }\end{array}$ & $\begin{array}{l}\text { Transitive vs. } \\
\text { Intransitive }\end{array}$ & $\begin{array}{l}\text { CR accepts that ideas are partially, but not } \\
\text { entirely, socially constructed. CR would also } \\
\text { argue that ideas have a material and structural } \\
\text { nature. }\end{array}$ \\
\hline & $\begin{array}{l}\text { Micro-level } \\
\text { politics }\end{array}$ & $\begin{array}{l}\text { Emergent levels } \\
\text { (structure \& } \\
\text { agency) }\end{array}$ & $\begin{array}{l}\text { CR is agnostic to the concept of micro-level } \\
\text { politics. However, it would also add that the } \\
\text { activities of actors (re)produce structural } \\
\text { relations (e.g. of power). }\end{array}$ \\
\hline \multirow[t]{3}{*}{$\begin{array}{l}\text { Symbolic } \\
\text { Interactionism }\end{array}$} & Boundaries & $\begin{array}{l}\text { Domain level } \\
\text { theory }\end{array}$ & $\begin{array}{l}\text { CR is agnostic to domain level theorising } \\
\text { providing there is sufficient evidence to support } \\
\text { the theory. }\end{array}$ \\
\hline & $\begin{array}{l}\text { Interactions } \\
\text { between } \\
\text { different } \\
\text { groups }\end{array}$ & $\begin{array}{l}\text { People \& } \\
\text { relations }\end{array}$ & $\begin{array}{l}\text { CR holds that relationality is a key emergent } \\
\text { property of people and groups. This includes } \\
\text { discursive, structural and material interactions. }\end{array}$ \\
\hline & $\begin{array}{l}\text { The power of } \\
\text { objects in } \\
\text { enabling co- } \\
\text { operation. }\end{array}$ & $\begin{array}{l}\text { Entities, Powers } \\
\& \text { Mechanisms }\end{array}$ & $\begin{array}{l}\text { CR accepts both the (intransigent) material } \\
\text { reality of objects, and the properties and } \\
\text { powers that this implies, as well as the } \\
\text { (transigent) shared discourses and theories by } \\
\text { which these objects are understood. }\end{array}$ \\
\hline
\end{tabular}

Here, we can see that CR's proposition of reality existing at different emergent levels allows its acceptance of macro-level entities such as social structures and populations of management ideas, as well as micro-level entities such as people, identities, and actions. Its commitment to a stratified ontology means that it accepts the domain of the actual favoured by positivism and actualism, but also the 'empirical' domain of discourse and human communication. Moreover, CR's conception of 
people accepts the powers of agency suggested by ANT, but also the potential to be rational suggested by scientism. Yet CR also accepts that what appears rational to people is affected by discourse, culture and communication (Archer 2000). Finally, we should note the agnosticism CR has for methods and domain-level theorising: unlike the other archetypes, CR does not have a preference for any specific approach to studying or theorising management ideas. Thus, CR can integrate at least some of the strengths of the different philosophies.

Concerning the limitations in the four philosophies (taken from Table 1), these can be grouped into five areas which CR also addresses (Table 3). The first concerns a reductionist ontology which accepts only one form of reality. For ANT and diffusion studies, this is the empirical actor-network, whereas for social constructivism, it is discourse ${ }^{5}$. The critical realist commitments to an emergent ontology, to entities (with properties) and to causal mechanisms, mean that discourse, events, materiality, people and relations are all ontologically permissible but not conflated. The second, is the exclusion of either a micro or macro view on reality. As we saw earlier, both are important in understanding management ideas. For $\mathrm{CR}$, the macro and micro are not conflated, but are mutually dependent (for example, agency and structure). The third, related to the first two, is an inadequate conceptualisation of humans, which are either ignored or reduced to a single phenomenon such as events (ANT) or discourse (social constructivism). By committing to emergence, CR accepts that humans are multilayered complex entities, with properties and powers that cannot be reduced to one dimension. The fourth is that by failing to distinguish between epistemology and ontology both constructivism and positivism generate 'flat' views of the world which struggle to find an explanation for why change occurs in their measures (either discourse or statistics) other than by referencing back to those entities. By making a distinction between the two, CR can not only posit that changes to discourse or statistics occur because of change at the level of the real, but also that our discourses or statistics may be mistaken or simply wrong. Explanation for CR comes from generating approximations of the causal mechanisms that exist. This provides critical realism with the capacity to provide richer explanations of why empirical events occur without resorting to mere correlations or descriptions

\footnotetext{
${ }^{5}$ This statement is subject to an ongoing debate concerning the ontological commitments of social constructivism (e.g. Fleetwood 2005). My simplified position on this is that if an author acknowledges the influence of an extra-discursive realm, they commit to some form of realism, and the onus is on them to be as precise as possible as to these commitments.
} 
Table 3:

Weaknesses of philosophical perspectives

\begin{tabular}{|c|c|c|}
\hline Ontology & Weaknesses & Problem category \\
\hline \multirow[t]{3}{*}{ Empiricism } & $\begin{array}{l}\text { Confuses survey / citation data with empirical } \\
\text { reality; }\end{array}$ & $\begin{array}{l}\text { No distinction between } \\
\text { epistemology and ontology }\end{array}$ \\
\hline & Produces 'thin' explanations & Lack of explanatory power \\
\hline & Humans excluded or presented as rational actors. & $\begin{array}{l}\text { Limited conception of } \\
\text { humans }\end{array}$ \\
\hline \multirow[t]{3}{*}{ Actualism } & Treats humans as equivalent to non-humans & $\begin{array}{l}\text { Limited conception of } \\
\text { humans }\end{array}$ \\
\hline & Difficulty with 'why' questions & Lack of explanatory power \\
\hline & Excludes non-empirics & $\begin{array}{l}\text { Reductionist / conflationary } \\
\text { ontology }\end{array}$ \\
\hline \multirow[t]{3}{*}{$\begin{array}{l}\text { Social } \\
\text { constructivism }\end{array}$} & $\begin{array}{l}\text { Focus on the local can miss the wider macro-level } \\
\text { view. (e.g. social structure; population level } \\
\text { descriptions). }\end{array}$ & $\begin{array}{l}\text { Reductionist / conflationary } \\
\text { ontology }\end{array}$ \\
\hline & $\begin{array}{l}\text { Focus on discourse means structure and the } \\
\text { material gets ignored }\end{array}$ & $\begin{array}{l}\text { No distinction between } \\
\text { epistemology and ontology }\end{array}$ \\
\hline & Difficulties conceptualising resistance. & $\begin{array}{l}\text { Limited conception of } \\
\text { humans (as subjects of } \\
\text { discourse). }\end{array}$ \\
\hline \multirow[t]{2}{*}{$\begin{array}{l}\text { Symbolic } \\
\text { interactionism }\end{array}$} & Ignores commonalities from wider context; & $\begin{array}{l}\text { View limited only to the } \\
\text { micro-level }\end{array}$ \\
\hline & Tends to under-play social structures & $\begin{array}{l}\text { View limited only to the } \\
\text { micro-level }\end{array}$ \\
\hline
\end{tabular}

\section{A critical realist definition of management ideas}

The principles of critical realism mean that we can begin to interrogate what a management idea is from this perspective. Before starting, there are three caveats. First, in order to avoid confusion, this definition concerns those common management ideas, such as BPR, TQM, Lean, and HRM which are specific approaches to organisation implemented in organisations, rather than the more ephemeral approaches such as 'greening'. Second, the definition is not meant to be definitive or final. It is a tentative start to illustrating what these types of ideas are. Finally, it should be stressed that critical realism is a meta-theory. It has been used as a foundation by many authors to underpin social theorising (for example concerning structure and agency, or reflexivity) and 'domain level theory' (for example, applying social theory to domains such as workplace conflict). The theorising below seeks to 
explicate a realist conception of ideas which includes critical realist meta-theory, and some common realist social theorising concerning structure and agency (Archer 2003).

Stratification: From a critical realist perspective, management ideas are discourses (texts and talk), practices (empirical routines) or ideas ${ }^{6}$ (thoughts or mental elaborations) about organising. These pertain to different types of reality which should not be conflated, for example, a management concept which does not currently exist may be written about in a prescriptive consultancy report; empirical routines may have evolved without being written down, talked or even thought about; and thoughts about a management idea might not be reflected either in any texts, nor in empirical practices. These distinctions allow slippage between what HRM, say, is in practice and what people believe it to be, or talk about it being - in CR terms, the distinction between the 'actual' and 'empirical'. This is important for three reasons. First, because managers (in completing surveys) and academics (when studying ideas) may be wrong in their identifications - claiming to 'have' or 'see' say teamworking when it does not exist in practice. Second, because some management innovations are often old wine in new bottles, and distinguishing between discourse and reality allows the observer to show that new rhetorics do not necessarily equate to new practices. Relatedly, and finally, discourses can be deceiving, with 'right-sizing', 'restructuring' and 're-engineering', for example, used as discursive tricks to hide the painful realities of redundancies.

Causal mechanisms: As most management ideas concern 'what works' in organising (normally improved efficiency), most imply (and more rarely state) causal mechanisms that link a feature of the management concept to an effect: for example, TQM improves quality by enabling workers to generate and implement improvements. Yet, as any manager or academic knows, social mechanisms are not that simple. A critical realist conceptualisation suggests that mechanisms may be actualised in certain contexts. For example, TQM may improve quality by enabling workers to generate and implement improvements when (among other things) there are high trust relations between managers and employees. Yet, even when a mechanism is actualised, there may be countervailing mechanisms (e.g. deteriorating machines; poor materials; budget reductions) which counteract the operation of the mechanism. Thus, in critical realist studies, one often sees the phrase 'ceteris paribus' - 'all other things being equal'. The specification of the causal mechanisms of a management idea also helps us understand the difference between an effective management idea and an ineffective one, in that a good management idea is one that contains an accurate understanding and explication of the causal mechanisms which tend to (ceteris paribus) produce the desired results. A bad idea, it follows, is one that has an inaccurate understanding of such mechanisms. This means that not all good management ideas work empirically.

It is also important to emphasise that it is not just the management idea that has causal powers, but also the idea of the idea. Thus, BPR, which had very high failure rates was popular in many companies as the idea of BPR is also a discursive entity in itself which has causal powers, for example, to attract consultancy clients or to resonate with prevailing economic conditions (O'Mahoney 2007). Thus, whilst the implied causal mechanisms of any idea might be wrong, this will not necessarily make it unpopular or impotent. This means that management concepts that are wrong (i.e. have flawed understanding of the mechanisms for 'success') can still be virulent.

Structure and agency: CR specifies a (re)productive relationship between structure (macro-level cultural and social contexts) and agency (the micro-level generation of ideas by consultants and gurus,

\footnotetext{
${ }^{6}$ Some might argue that ideas are discourses, but I would argue that there are enough differences between an individual's mental elaborations (which, let's face it, are sometimes pre-linguistic) and a book. A theory of existence which cannot distinguish between such differences is not a particularly useful theory for our purposes.
} 
and the implementation of these in organisations) (Grint and Case 1998). Agency is influenced by structure through social and cultural conditioning (e.g. the 'disciplining' of workers through discourse), which means that management ideas are intrinsically ideological - often concerned with the normalisation of neo-liberal forms of capitalism. As such, management ideas exist in relation to other ideas which can provide enabling (or countervailing) conditions. Thus ideas such as privatisation, freetrade, laissez-faire government, New Public Management, competitive tendering, and outsourcing, can be seen as 'complexes' (Elder-Vass 2010) which have logical resonance with each-other as part of a wider ideology of neo-liberalism. This emphasises the importance of the content (i.e. properties) of ideas themselves rather than simply framing them as mere constructions.

To summarise, a critical realist conception of management ideas is that they are real entities, but can be real in different ways (discursive, empirical and ideational senses) (Fleetwood 2005). They 'work' (or otherwise) through causal mechanisms which interact with social contexts to produce effects. Management ideas also have properties which make them different to each-other and provide logical coherence (or otherwise) with other ideas. Furthermore, management ideas contribute to the reproduction of the social structures which condition them, and in turn condition the agents which enact them.

\section{Conclusion}

This chapter argued that there has been little philosophical interrogation of management ideas which has led to three problems: lack of clarity on exactly what an author means by a management idea; lack of interdisciplinarity and a 'siloing' of the field; and veracity - a lack of critical interrogation of the assumptions of each silo by alternative approaches. The chapter then outlines the strengths and weaknesses of four approaches that underpin the extant literature, namely positivism, interactionism, actualism, and social constructivism. The chapter argues that whilst each provides its own insights, their ontological strictures mean that engagement with, and insights from, other perspectives, are limited, and thus their analyses are frequently limited and limiting. The chapter then introduces a critical realism, arguing that its stratified, emergent and realist ontology can (partially) integrate the insights from the four other philosophies, whilst ameliorating their respective weaknesses.

I am aware of the provocative, and probably arrogant, nature of this argument. It comes close to the 'insufferably smug [and] extraordinarily naive' (Van Maanen 1995: 133) call of Pfeffer (1993) for organization studies to develop a specific, consensually approved paradigm, upon which to better develop the field's legitimacy, progress and quality. A similar charge might be made of this chapter, but it would be misplaced. The focus of my critique is not (as Pfeffer's was) on the theoretical or methodological diversity of the field - indeed, I have shown that such variety is complimentary with a CR ontology - but rather on the exclusivity of other philosophies, whose ontological strictures discourage interdisciplinary exchange. Indeed, I would argue that the insights of ANT, positivism, interactionism and social constructivism do not come from their ontological, but their methodological preferences, which pose no challenge to a critical realist ontology.

Critical realism is by no means the final word. Its limitations are well known (Al-Amoudi and Willmott 2011, Cruickshank 2004) and it has been subject to refinement, not least by Bhaskar himself (Bhaskar 2008). Moreover, as an ontology, it is difficult to operationalise, and in the field of management ideas has had little use. As such, of course, it provides opportunities, as well as challenges, for researchers. 


\section{References}

Abrahamson, E. \& Fairchild, G. 1999. 'Management fashion: Lifecycles, triggers, and collective learning processes.' ADMINISTRATIVE SCIENCE QUARTERLY, 44:4, 708-40.

Al-Amoudi, I. \& Willmott, H. 2011. 'Where Constructionism and Critical Realism Converge: Interrogating the Domain of Epistemological Relativism.' Organization Studies, 32:1, 27-46.

Annels, M. 2010. 'Grounded theory method.' In P. Atkinson \& S. Delamont (Eds.) SAGE Qualitative Research Methods: 13-27. London: Sage.

Archer, M. S. 2000. 'Being Human: The Problem of Agency.' 42, 323.

Archer, M. S. 2003. 'Structure, Agency and the Internal Conversation.' 9, 384.

Barad, K. 2007. Meeting the Universe Halfway: Quantum Physics and the Entanglement of Matter and Meaning. Duke University Press.

Bechky, B. A. 2003. 'Sharing meaning across occupational communities: The transformation of understanding on a production floor.' Organization Science, 14:3, 312-30.

Benders, J., Nijholt, J. \& Heusinkveld, S. 2007. 'Using print media indicators in management fashion research.' Quality \& Quantity, 41:6, 815-29.

Bhaskar, R. 1975. A Realist Theory of Science. Routledge.

Bhaskar, R. 2008. Dialectic : the pulse of freedom. London ; New York: Routledge.

Bhaskar, R. 2011. Philosophy and the idea of freedom. London; New York: Routledge.

Bijker, W. E. \& Law, J. 1992. Shaping Technology/building Society: Studies in Sociotechnical Change. USA: MIT Press.

Birkinshaw, J., Hamel, G. \& Mol, M. J. 2008. 'Management Innovation.' The Academy of Management Review, 33, 825.

Blumer, H. 1962. ' Society as Symbolic Interaction.' In A. Rose (Ed.) Human Behavior and Social Process: An Interactionist Approach: 62-98. New York: Houghton-Mifflin.

Blumer, H. 1986. Symbolic Interactionism: Perspective and Method. University of California Press.

Clark, T. A. R. 2004. 'The fashion of management fashion: a surge too far?' Organization, 11, 297306.

Collinson, M., Rees, C., Edwards, P. K. \& Inness, L. 1998. Involving Employees in Total Quality Management: Employee Attitudes and Organisational Context in Unionised Environments. Department of Trade and Industry London.

Cruickshank, J. 2004. 'A tale of two ontologies: an immanent critique of critical realism.' The Sociological Review, 52:4, 567-85.

Czarniawska-Joerges, B. \& Sevón, G. 2005. Global ideas: how ideas, objects and practices travel in a global economy. Liber \& Copenhagen Business School Press.

Czarniawska, B. 2012. 'Operational Risk, Translation, and Globalization.' Contemporary Economics, 6:2, 26.

Elder-Vass, D. 2010. The Causal Power of Social Structures: Emergence, Structure and Agency. Cambridge: Cambridge University Press.

Elder-Vass, D. 2008. 'Searching for realism, structure and agency in Actor Network Theory.' The British Journal of Sociology, 59:3, 455-73.

Fleetwood, S. 2005. 'Ontology in organization and management studies: a critical realist perspective.' Organization, 12, 197-222.

Fleetwood, S. \& Hesketh, A. 2015. 'Prediction in Social Science.' Journal of Critical Realism.

Frandsen, A.-C. 2010. 'The role of disciplining/translating accounting practices in patient-centred care.' The International Journal of Public Sector Management, 23:4, 381-91.

Giroux, H. 2006. 'It Was Such a Handy Term': Management Fashions and Pragmatic Ambiguity*.' Journal of Management Studies, 43:6, 1227-60.

Grint, K. \& Case, P. 1998. 'The Violent Rhetoric of Re-engineering: Management Consultancy on the Offensive.' Journal of Management Studies, 35:5, 557-77.

Guilloux, V., Locke, J. \& Lowe, A. 2013. 'Digital business reporting standards: mapping the battle in France.' European Journal of Information Systems, 22:3, 257-77. 
Harrisson, D. \& Laberge, L. 2002. 'Innovation, identities and resistance: The social construction of an innovation network.' Journal of Management Studies, 39, 497-521.

Kelemen, M. 2000. 'Too much or too little ambiguity: The language of total quality management.' Journal of Management Studies, 37:4, 483-98.

Knights, D; M. \& D 2003. 'Governing through teamwork: Reconstituting subjectivity in a call centre.' Journal of Management Studies, 40, 1587-619.

Laclau, E. \& Mouffe, C. 2001. Hegemony and Socialist Strategy: Towards a Radical Democratic Politics. Verso.

Latour, B. 2007. Reassembling the Social: An Introduction to Actor-Network-Theory. OUP Oxford.

Latour, B. \& Woolgar, S. 1986. Laboratory Life: The Construction of Scientific Facts. Princeton University Press.

Law, J. \& Mol, A. 2008. 'The actor-enacted: Cumbrian sheep in 2001.' In C. Knappet \& L. Malafouris (Eds.) Material agency: towards a non-anthropocentric approach: 57-96. New York: Springer.

Luoma-aho, V. \& Paloviita, A. 2010. 'Actor-networking stakeholder theory for today's corporate communications.' Corporate Communications, 15:1, 49-67.

McKinley, W., Mone, M. A. \& Moon, G. 1999. 'Determinants and development of schools in organization theory.' Academy of Management Review, 24:4, 634-48.

Morris, T. \& Lancaster, Z. 2006. 'Translating Management Ideas.' Organization Studies, 27:2, 207-33.

Mutch, A. 2007. 'Making connections: agency, reflexivity and structure.' 2-3.

O'Mahoney, J. 2007. 'The Diffusion of Management Innovations: The Possibilities and Limitations of Memetics.' Journal of Management Studies, 44, 1324-48.

O'Mahoney, J. 2011. 'Embracing essentialism: A realist critique of resistance to discursive power.' Organization, 19:6, 723-41.

O'Mahoney, J. 2016. 'Archetypes of Translation: Recommendations for Dialogue.' International Journal of Management Reviews, 18:3, 333-50.

O'Mahoney, J. \& Vincent, S. 2014. 'Critical realism as an empirical project: a beginner's guide.' In P. Edwards, J. O'Mahoney \& S. Vincent (Eds.) Putting Critical Realism into Practice: A Guide to Research Methods in Organization Studies. London: Oxford University Press.

Pawlowski, S. D. \& Robey, D. 2004. 'Bridging user organizations: Knowledge brokering and the work of information technology professionals.' MIS Quarterly, 645-72.

Peirce, C. S. 1998. The Essential Peirce, Selected Philosophical Writings, Volume 1 (1893-1913). Indianapolis, IN,: Indiana University Press.

Pfeffer, J. 1993. 'Barriers to the advance of organizational science: Paradigm development as a dependent variable.' Academy of Management Review, 18:4, 599-620.

Porpora, D. V. 2015. Reconstructing Sociology: The Critical Realist Approach. Cambridge University Press.

Reay, T., Chreim, S., Golden-Biddle, K., Goodrick, E., Williams, B. E., Casebeer, A., Pablo, A. \& Hinings, C. 2013. 'Transforming new ideas into practice: An activity based perspective on the institutionalization of practices.' Journal of Management Studies, 50:6, 963-90.

Robinson, S., Lockett, N., Smith, S., Rose, M. \& Hamilton, E. 2010. 'The story of a university knowledge exchange actor-network told through the sociology of translation: A case study.' International Journal of Entrepreneurial Behavior \& Research, 16:6, 502-16.

Sahlin-Andersson, K. \& Engwall, L. 2002. 'The expansion of management knowledge: carriers, flows, and sources.' 373.

Sandhu, R., Baxter, J. \& Emsley, D. 2008. 'The Balanced Scorecard and its Possibilities: The Initial Experiences of a Singaporean Firm.' Australian Accounting Review, 18:1, 16-24.

Smith, C. \& Pun, N. 2006. 'The dormitory labour regime in China as a site for control and resistance 1.' The International Journal of Human Resource Management, 17:8, 1456-70.

Star, S. L. \& Griesemer, J. R. 1989. 'Institutional ecology, translations' and boundary objects: Amateurs and professionals in Berkeley's Museum of Vertebrate Zoology, 1907-39.' Social Studies of Science, 19:3, 387-420. 
Strang, D., David, R. J. \& Akhlaghpour, S. 2014. 'Coevolution in management fashion: An agent-based model of consultant-driven innovation.' American Journal of Sociology, 120:1, 226-64.

Strauss, A. 1959. Mirrors and Masks. Glencoe, IL: The Free Press.

Strong, M. \& Letch, N. 2013. 'Investigating cultural heritage data integration with an ANT perspective.' Vine, 43:3, 322-40.

Sturdy, A. 2004. 'The adoption of management ideas and practices: theoretical perspectives and possibilities.' Management Learning, 35, 155-79.

Swan, J., Bresnen, M., Newell, S. \& Robertson, M. 2007. 'The object of knowledge: The role of objects in biomedical innovation.' HUMAN RELATIONS, 60:12, 1809-37.

Terziovski, M., Fitzpatrick, P. \& O'Neill, P. 2003. 'Successful predictors of business process reengineering (BPR) in financial services.' International Journal of Production Economics, 84:1, 35-50.

Thompson, P. \& Ackroyd, S. 1995. 'All quiet on the workplace front? A critique of recent trends in British industrial sociology.' Sociology, 29:4, 615-33.

Van Maanen, J. 1995. 'Crossroads style as theory.' Organization Science, 6:1, 133-43.

Waarts, E. \& Van Everdingen, Y. 2005. 'The Influence of National Culture on the Adoption Status of Innovations:: An Empirical Study of Firms Across Europe.' European Management Journal, 23:6, 601-10.

Wenger, E. 1999. Communities of Practice: Learning, Meaning, and Identity. Cambridge University Press. 